\title{
Experimental asbestosis: an investigation of functional and pathological disturbances. I. Methods, control animals and exposure conditions
}

\author{
D. M. HIETT $\dagger$
}

From the Department of Occupational Health, University of Manchester, Stopford Building, Oxford Road, Manchester M13 9PT

ABSTRACT The measurement of respiratory function and quantitative assessment of changes in lung morphology are described in a long-term study of asbestos-exposed guinea pigs. Resistance and dynamic compliance of the guinea pig respiratory system were measured non-destructively, and the tidal volume and rate of spontaneous breathing were also determined. A point counting technique was used with histological preparations to quantify morphological changes. In one group of control animals, investigated between 3 and 28 months of age, dynamic compliance and tidal volume tended to increase, but resistance and breathing rate tended to decrease, as the animals matured. In contrast the percentage by volume of various lung components remained constant throughout this period. The animals were exposed to chrysotile and amosite aerosols, both aerosols containing high concentrations of short fibres $(<5 \mu \mathrm{m})$ and at least 1000 fibres/ml longer than $5 \mu \mathrm{m}$. The total fibre concentration during chrysotile exposure was probably at least double that during amosite exposure. A gradient of fibre concentration $(<5 \mu \mathrm{m})$ was detected along the exposure chamber, but this gradient was not reflected in the respiratory function of animals exposed at different positions along the chamber. These findings are discussed in relation to possible dose-dependence of the response.

Recent investigations have provided valuable information concerning the development of disturbances in respiratory function in workers exposed to asbestos dust (Bader et al., 1970; Coleman Muldoon and Turner Warwick, 1972; Becklake et al., 1972). Work on the early pathological changes in humans has been less extensive, although this has, in many ways, been compensated for by numerous animal experiments (Wagner, 1963; Holt et al., 1966; Timbrell and Skidmore, 1968). This paper (Parts I and II) describes a study in which both pathological and physiological assessments were recorded during the development of experimental asbestosis in guinea pigs that had inhaled chrysotile or amosite fibres. The physiological and histological changes in control animals, and the estimation of exposure conditions, are described in Part I. Part II (British

*This paper is based on part of work accepted as a $\mathrm{PhD}$ thesis by the University of Manchester, 1973.

†Present address: The National Ocsupational Hygiene Service Ltd., 12 Brook Road, Fallowfield, Manchester M14 6UH

Received for publication 23 March 1976

Accepted for publication 12 October 1977
Journal of Industrial Medicine, 1978, 35, 135-145) describes the results following the asbestos exposures and includes a general discussion.

\section{Methods}

The male guinea pigs used for this investigation were originally specific pathogen-free. They were kept in isolation from other experimental animals, and were fed an irradiated high vitamin $\mathrm{C}$ diet. Identification numbers were tattooed on the ear lobes, and the animals were weighed regularly.

Respiratory function was assessed using the techniques described by Hiett (1974). Respiratory resistance was determined by the forced oscillation method. Extrathoracic pressure oscillations were applied with the animal resting in a partial body plethysmograph, while the resultant oscillation of air flow at the airways opening was measured by a pneumotachograph. Tidal volume and breathing rate measurements were made from the pneumotachograph signal when the extrathoracic pressure was not oscillated. Dynamic respiratory compliance was also determined with the animal at rest in the 
plethysmograph. The test essentially measures the increase in end expiratory volume resulting from a unit drop in extrathoracic pressure. These measurements were made at regular intervals throughout experiments on both control and exposed animals.

At regular intervals lungs were removed from randomly selected animals for histological preparation. The animals were killed by inhalation of fluothane, and the trachea was tied off before the thorax was opened, leaving the lungs at their resting volume. After fixation in $10 \%$ buffered formalin, whole lobe sections of the upper and lower lobes of the right lung were stained with haematoxylin and eosin, Van Gieson stain, Mason's trichrome, and Prussian blue.

The quantitative morphology and degree of pathological disturbance was assessed by the point counting technique for the relative volumes of lung parenchymal components (Dunnill, 1962a). An eyepiece graticule marked with 20 points was superimposed on numerous low-power fields of lung sections, and the classified components (Table 1) that fell immediately beneath these points were recorded. The relative frequency with which randomly distributed components are observed, can be shown to be proportional to the relative volumes occupied by each. Dunnill (1962a) found that counts of 500-1000 points per section gave consistent results for parenchymal components of human lungs. In this study between 1500 and 3000 points were counted over the lung sections of each animal.

Animals were exposed to either chrysotile or amosite aerosols in the equipment described by Holt et al (1964). The exposure chamber is illustrated diagrammatically in the Figure, and animals were accomodated in the front and rear cages. During exposure, which lasted for either 9 or 18 days, the dust concentration within the chamber was continually monitored by a recording tyndallometer. This instrument was calibrated by quantitative dust sampling, as described by Harness (1973). The samples were collected on membrane filters and were observed under phase contrast light microscopy $(\times 500)$. An assessment of the numbers of fibres

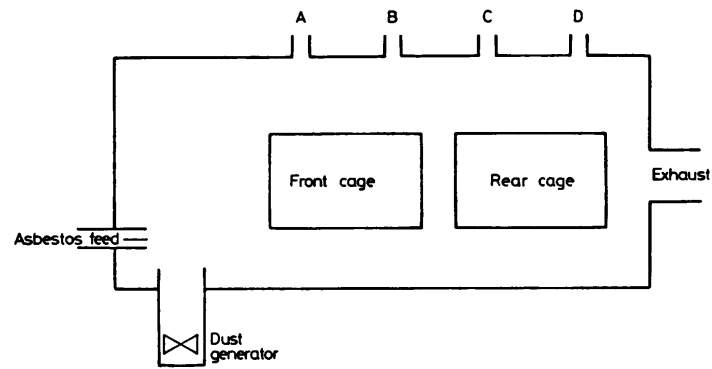

Figure Diagram of the inhalation tunnel (after Holt et al., 1964).

longer than $5 \mu \mathrm{m}$ was made by the Department of Health Physics, Turner Brothers Asbestos Co. Ltd., Rochdale.

These results indicated that there was a higher concentration of long fibres in the air above the front cage of the exposure chamber than in the air above the rear cage. The possible effect of this difference on respiratory function of the groups of animals exposed in each cage was investigated. The first measurements after exposure were considered to provide the best comparison in this respect.

\section{Results}

\section{CONTROL ANIMALS}

\section{Physiological changes}

For ease of description the simple terms resistance and compliance are used to refer to total respiratory resistance and total dynamic compliance respectively, unless otherwise stated.

One group of control animals was studied from the age of 3-28 months. The mean weight increased from $471 \mathrm{~g}$ to $901 \mathrm{~g}$ between the ages of 3-7 months, then gradually declined to $666 \mathrm{~g}$ at 28 months. The mean resistance fell from 0.64 to $0.33 \mathrm{cmH}_{2} \mathrm{O} / \mathrm{ml} / \mathrm{s}$ during the first five months of the study, but further changes showed no consistent trend. The mean compliance and tidal volume increased gradually,

Table 1 Structure classification for the point counting technique

\begin{tabular}{ll}
\hline Structure classification & Structures and tissues counted \\
\hline Normal alveoli & All tissues and air spaces, distal to respiratory bronchioles. \\
Small blood vessels & Blood vessels excluding those associated with bronchi. \\
Large bronchioles & $\begin{array}{l}\text { Normal bronchioles distal to the last plate of cartilage but proximal to the terminal } \\
\text { bronchioles. } \\
\text { Terminal bronchioles with normal structure. }\end{array}$ \\
Terminal bronchioles & $\begin{array}{l}\text { Respiratory bronchioles with normal structure. } \\
\text { Respiratory bronchioles }\end{array}$ \\
$\begin{array}{l}\text { Damaged alveoli } \\
\text { Obliterated bronchioles } \\
\text { Bronchioles with thickened walls }\end{array}$ & $\begin{array}{l}\text { Bronchioles with totally disrupted structure. } \\
\text { Bronchioles with peribronchiolar thickening. }\end{array}$ \\
\hline
\end{tabular}


Table 2 Percentage by volume of various structures for control animals

\begin{tabular}{|c|c|c|c|c|c|c|c|c|c|c|c|c|c|c|c|}
\hline Structure & $\begin{array}{l}\text { Percen } \\
4\end{array}$ & tage by & $\begin{array}{l}\text { volum } \\
9\end{array}$ & 11 & $\begin{array}{l}\text { uctures } \\
11\end{array}$ & in anir & $\begin{array}{l}\text { mals of } \\
18\end{array}$ & $\begin{array}{l}\text { various } \\
20\end{array}$ & $\begin{array}{l}s \text { ages } \\
20\end{array}$ & months & 27 & 28 & $M e a n \pm S D$ & $C V \%$ & $\begin{array}{l}\text { Correlation } \\
\text { coefficient }\end{array}$ \\
\hline Normal alveoli & $92 \cdot 4$ & $96 \cdot 2$ & $94 \cdot 3$ & $96 \cdot 2$ & $95 \cdot 4$ & $93 \cdot 5$ & 93.0 & 93.4 & $95 \cdot 4$ & $94 \cdot 0$ & $95 \cdot 7$ & $93 \cdot 5$ & $94 \cdot 4 \pm 1 \cdot 31$ & $1 \cdot 4$ & $0.025 \mathrm{NS}$ \\
\hline Small blood vessels & $3 \cdot 5$ & $1 \cdot 4$ & 1.9 & $2 \cdot 8$ & $2 \cdot 5$ & $3 \cdot 3$ & $4 \cdot 4$ & $4 \cdot 4$ & $2 \cdot 5$ & $3 \cdot 2$ & $2 \cdot 4$ & $3 \cdot 7$ & $3.0 \pm 0.93$ & 31 & $0.33 \mathrm{NS}$ \\
\hline Large bronchioles & $1 \cdot 8$ & $1 \cdot 2$ & 1.9 & 0.5 & 0.9 & $1 \cdot 2$ & 1.4 & 0.9 & $1 \cdot 0$ & $1 \cdot 3$ & 1.0 & $1 \cdot 4$ & $1.2 \pm 0.39$ & 33 & $0.24 \mathrm{NS}$ \\
\hline Terminal bronchioles & 1.0 & 0.5 & 0.6 & 0.2 & 0.5 & $1 \cdot 1$ & 0.6 & $1 \cdot 1$ & 0.8 & 0.8 & $0 \cdot 4$ & 0.9 & $0.7 \pm 0.29$ & 41 & $0.13 \mathrm{NS}$ \\
\hline $\begin{array}{l}\text { Respiratory } \\
\text { bronchioles }\end{array}$ & $1 \cdot 4$ & 0.6 & 0.9 & $0 \cdot \overline{3}$ & 0.6 & 0.9 & 0.7 & $0 \cdot 2$ & 0.3 & 0.7 & 0.5 & 0.5 & $0.6 \pm 0.33$ & 55 & $0.54 \mathrm{NS}$ \\
\hline Total bronchioles & $4 \cdot 2$ & $2 \cdot 3$ & $3 \cdot 4$ & $1 \cdot 0$ & $2 \cdot 0$ & $3 \cdot 2$ & $2 \cdot 7$ & $2 \cdot 2$ & $2 \cdot 1$ & $2 \cdot 8$ & 1.9 & $2 \cdot 8$ & $2.6 \pm 0.83$ & 32 & $0.29 \mathrm{NS}$ \\
\hline $\begin{array}{l}\text { Number of points } \\
\text { counted }\end{array}$ & 2525 & 3836 & 1152 & 3478 & 1917 & 2787 & 1590 & 4328 & 4060 & 3678 & 1441 & 2002 & - & - & - \\
\hline
\end{tabular}

*CV $=$ coefficient of variation NS $=$ not significant.

from $0.15 \mathrm{ml} / \mathrm{cmH}_{2} \mathrm{O}$ and $2.8 \mathrm{ml}$ respectively at 3 months, to maximum values of $0.40 \mathrm{ml} / \mathrm{cmH}_{2} \mathrm{O}$ and $4.9 \mathrm{ml}$ at 22 months of age. During the 25 -month study the mean breathing rate fell from 86 to 58 breaths per minute.

The changes in respiratory function of the other control groups followed similar trends to those described above. However, some differences in time scale and magnitude of these changes were apparent between groups, indicating the need for a wellmatched control group in each experiment.

\section{Histological changes}

The quantitative histological findings for 12 control animals, aged 4-28 months, are given in Table 2 . The percentage volume occupied by normal alveolar tissue was remarkably constant for all animals, while the percentage volumes of other components proved to be more variable. The coefficient of variation of the percentage volumes occupied by small blood vessels and large bronchioles was just over $30 \%$, but was $41 \%$ for terminal bronchioles and $55 \%$ for respiratory bronchioles. The latter two both occupied relatively small percentages of the total volume. Correlation analysis indicated that the percentage volumes of the lung components studied were independent of age from 4 to 28 months.

\section{ASSESSMENT OF EXPOSURE CONDITIONS}

Exposure conditions were regulated to maintain a tyndallometer reading between $20-30 \mu \mathrm{A}$ at position A along the exposure chamber (Figure). However, during chrysotile exposures slight fluctuations outside these limits were unavoidable, while during amosite exposures considerable fluctuations occurred and values from zero to well over $30 \mu \mathrm{A}$ were registered.

Samples from position $\mathrm{A}$ indicated that some $20 \%$ of fibres in the chrysotile aerosol, and some $10 \%$ of fibres in the amosite aerosol were longer than $5 \mu \mathrm{m}$. Samples from positions further along the chamber indicated that the percentage of long fibres in both aerosols decreased as distance from the dust generator increased. Fibres longer than $5 \mu \mathrm{m}$ were counted with an accuracy considered to be $\pm 50 \%$. The results were expressed in terms of fibres $(>5 \mu \mathrm{m})$ per millilitre of air sampled, and are given in Table 3, for the chrysotile aerosol, and Table 4, for the amosite aerosol. The corresponding tyndallometer readings were made at the same position just before each sample was collected.

Table 3 Number of fibres in chrysotile aerosol

\begin{tabular}{lcll}
\hline $\begin{array}{l}\text { Position of } \\
\text { sample along } \\
\text { chamber* }\end{array}$ & $\begin{array}{l}\text { Volume } \\
\text { sampled } \\
(\mathrm{ml})\end{array}$ & $\begin{array}{l}\text { Fibre } \\
\text { concentration } \\
\text { (fibres } / \mathrm{ml})\end{array}$ & $\begin{array}{l}\text { Tyndallometer } \\
\text { reading } \\
(\mu \mathrm{A})\end{array}$ \\
\hline A & 500 & 4300 & 20 \\
A & 200 & 4100 & 18 \\
A & 1000 & 4300 & 18 \\
A & 220 & 4800 & 15 \\
B & 230 & 3400 & 12 \\
C & 220 & 2800 & 10 \\
D & 230 & 1600 & 7 \\
\hline
\end{tabular}

*See Figure.

Table 4 Number of fibres in amosite aerosol

\begin{tabular}{llll}
\hline $\begin{array}{l}\text { Position of } \\
\text { sample along } \\
\text { chamber* }\end{array}$ & $\begin{array}{l}\text { Volume } \\
\text { sampled } \\
(\mathrm{m} I)\end{array}$ & $\begin{array}{l}\text { Fibre } \\
\text { concentration } \\
(\text { fibres } / \mathrm{ml})\end{array}$ & $\begin{array}{l}\text { Tyndallometer } \\
\text { reading } \\
(\mu \mathrm{A})\end{array}$ \\
\hline A & 100 & 940 & 16 \\
A & 100 & 2700 & 50 \\
A & 100 & 1250 & 20 \\
B & 100 & 1100 & 15 \\
C & 100 & 450 & 6 \\
D & 100 & 390 & 4 \\
\hline
\end{tabular}

*See Figure.

The first three samples from the chrysotile aerosol show that consistent fibre concentrations were obtained while the tyndallometer reading remained steady. The first two samples from the amosite aerosol demonstrate the considerable fluctuations in tyndallometer reading, mostly caused by alterations in asbestos feed to the dust generator. The final four samples in both Tables were taken from each 
Table 5 Comparison of respiratory function of animals exposed to amosite in the front and rear cages of the exposure chamber

\begin{tabular}{|c|c|c|c|c|c|c|c|c|c|c|c|}
\hline \multirow{2}{*}{$\begin{array}{l}\text { Exposure } \\
\text { classification } \\
\text { and code }\end{array}$} & \multirow{2}{*}{$\begin{array}{l}\text { Respiratory } \\
\text { function } \\
\text { test* }\end{array}$} & \multicolumn{5}{|c|}{ Preliminary measurements } & \multicolumn{5}{|c|}{ First measurements after exposure } \\
\hline & & $\begin{array}{l}\text { Group to be } \\
\text { placed in } \\
\text { front cage }\end{array}$ & $\begin{array}{l}\text { Group to be } \\
\text { placed in } \\
\text { rear cage }\end{array}$ & $t$ & $d f$ & $\boldsymbol{P}$ & $\begin{array}{l}\text { Group placed } \\
\text { in front cage }\end{array}$ & $\begin{array}{l}\text { Group placed } \\
\text { in rear cage }\end{array}$ & $t$ & $d f$ & $P$ \\
\hline $\begin{array}{l}\text { Amosite } \\
\text { exposure for } \\
9 \text { days } \\
\text { (A1) }\end{array}$ & $\begin{array}{l}\text { Resistance } \\
\text { Compliance } \\
\text { Tidal volume } \\
\text { Breathing rate }\end{array}$ & $\begin{array}{l}0 \cdot 30(n=6) \\
0 \cdot 16(n=5) \\
2 \cdot 7 \quad(n=5) \\
71 \quad(n=5)\end{array}$ & $\begin{array}{l}C \cdot 30 \quad(n=6) \\
0 \cdot 18(n=5) \\
3 \cdot 2 \quad(n=5) \\
80 \quad(n=5)\end{array}$ & $\begin{array}{l}0 \cdot 19 \\
2 \cdot 46 \\
1 \cdot 41 \\
1 \cdot 59\end{array}$ & $\begin{array}{r}10 \\
8 \\
8 \\
8\end{array}$ & $\begin{array}{l}\text { NS } \\
\text { NS } \\
\text { NS } \\
\text { NS }\end{array}$ & $\begin{array}{l}0.37(n=5) \\
0.07(n=6) \\
1.9 \quad(n=6) \\
110(n=6)\end{array}$ & $\begin{array}{l}0.37(n=5) \\
0.07(n=6) \\
2.3 \quad(n=6) \\
110(n=6)\end{array}$ & $\begin{array}{l}0 \cdot 22 \\
0 \cdot 32 \\
1 \cdot 23 \\
0 \cdot 02\end{array}$ & $\begin{array}{r}8 \\
10 \\
10 \\
10\end{array}$ & $\begin{array}{l}\text { NS } \\
\text { NS } \\
\text { NS } \\
\text { NS }\end{array}$ \\
\hline $\begin{array}{l}\text { Amosite } \\
\text { exposure for } \\
18 \text { days } \\
\text { (A2) }\end{array}$ & $\begin{array}{l}\text { Resistance } \\
\text { Compliance } \\
\text { Tidal volume } \\
\text { Breathing rate }\end{array}$ & $\begin{array}{ll}0.41 & (n=9) \\
0.13 & (n=9) \\
2 \cdot 3 & (n=9) \\
71 \quad(n=9)\end{array}$ & $\begin{array}{l}0.40(n=9) \\
0.15(n=9) \\
2.4 \quad(n=9) \\
70 \quad(n=9)\end{array}$ & $\begin{array}{l}0 \cdot 10 \\
1 \cdot 24 \\
0 \cdot 37 \\
0 \cdot 19\end{array}$ & $\begin{array}{l}16 \\
16 \\
16 \\
16\end{array}$ & $\begin{array}{l}\text { NS } \\
\text { NS } \\
\text { NS } \\
\text { NS }\end{array}$ & $\begin{array}{l}0.33(n=8) \\
0.13(n=8) \\
2 \cdot 3 \quad(n=8) \\
93 \quad(n=8)\end{array}$ & $\begin{array}{l}0 \cdot 32(n=4) \\
0 \cdot 15(n=9) \\
2 \cdot 2 \quad(n=9) \\
92 \quad(n=9)\end{array}$ & $\begin{array}{l}0.20 \\
1 \cdot 18 \\
0.31 \\
0.06\end{array}$ & $\begin{array}{l}10 \\
15 \\
15 \\
15\end{array}$ & $\begin{array}{l}\text { NS } \\
\text { NS } \\
\text { NS } \\
\text { NS }\end{array}$ \\
\hline
\end{tabular}

$t=$ Student's $t ; d f=$ degrees of freedom; $P=$ probability; NS $=$ not significant, in this and the following table

*Resistance in $\mathrm{cmH}_{2} \mathrm{O} / \mathrm{ml} / \mathrm{s}$; compliance in $\mathrm{ml} / \mathrm{CmH}_{2} 0$; tidal volume in $\mathrm{ml}$; breathing rate in breaths $/ \mathrm{min}$

Table 6 Comparison of respiratory function of animals exposed to chrysotile in the front and rear cages of the exposure chamber

\begin{tabular}{|c|c|c|c|c|c|c|c|c|c|c|c|}
\hline \multirow{2}{*}{$\begin{array}{l}\text { Exposure } \\
\text { classification } \\
\text { and } \\
\text { code }\end{array}$} & \multirow{2}{*}{$\begin{array}{l}\text { Respiratory } \\
\text { function } \\
\text { test* }\end{array}$} & \multicolumn{5}{|c|}{ Preliminary measurements } & \multicolumn{5}{|c|}{ First measurements after exposure } \\
\hline & & $\begin{array}{l}\text { Group to be } \\
\text { placed in } \\
\text { front cage }\end{array}$ & $\begin{array}{l}\text { Group to be } \\
\text { placed in } \\
\text { rear cage }\end{array}$ & $t$ & $d f$ & $P$ & $\begin{array}{l}\text { Group placed } \\
\text { in front cage }\end{array}$ & $\begin{array}{l}\text { Group placed } \\
\text { in rear cage }\end{array}$ & $t$ & $d f$ & $P$ \\
\hline $\begin{array}{l}\text { Chrysotile } \\
\text { exposure for } \\
9 \text { days } \\
\text { (C1) }\end{array}$ & $\begin{array}{l}\text { Resistance } \\
\text { Compliance } \\
\text { Tidal volume } \\
\text { Breathing rate }\end{array}$ & $\begin{array}{l}0 \cdot 65(n=12) \\
0 \cdot 18(n=12) \\
2 \cdot 9 \quad(n=13) \\
88 \quad(n=13)\end{array}$ & $\begin{array}{l}0.68(n=13) \\
0 \cdot 17(n=12) \\
2 \cdot 7 \quad(n=12) \\
82 \quad(n=12)\end{array}$ & $\begin{array}{l}1.01 \\
0.63 \\
0.82 \\
2.45\end{array}$ & $\begin{array}{l}23 \\
22 \\
23 \\
23\end{array}$ & $\begin{array}{c}\text { NS } \\
\text { NS } \\
\text { NS } \\
<0.05 \\
>0.02\end{array}$ & $\begin{array}{l}0 \cdot 55(n=10) \\
0 \cdot 06(n=10) \\
2 \cdot 3 \quad(n=10) \\
148 \quad(n=10)\end{array}$ & $\begin{array}{c}0.56(n=12) \\
0.07(n=12) \\
2 \cdot 1 \quad(n=12) \\
130(n=12)\end{array}$ & $\begin{array}{l}0 \cdot 18 \\
1 \cdot 35 \\
1 \cdot 20 \\
1 \cdot 84\end{array}$ & $\begin{array}{l}20 \\
20 \\
20 \\
20\end{array}$ & $\begin{array}{l}\text { NS } \\
\text { NS } \\
\text { NS } \\
\text { NS }\end{array}$ \\
\hline $\begin{array}{l}\text { Chrysotile } \\
\text { exposure for } \\
18 \text { days } \\
\text { (C2) }\end{array}$ & $\begin{array}{l}\text { Resistance } \\
\text { Compliance } \\
\text { Tidal volume } \\
\text { Breathing rate }\end{array}$ & $\begin{array}{l}0 \cdot 29(\mathrm{n}=8) \\
0 \cdot 18(\mathrm{n}=9) \\
2 \cdot 3 \quad(\mathrm{n}=9) \\
62 \quad(\mathrm{n}=9)\end{array}$ & $\begin{array}{l}0 \cdot 26(n=7) \\
0 \cdot 19(n=7) \\
2 \cdot 6 \quad(n=7) \\
69 \quad(n=7)\end{array}$ & $\begin{array}{l}0.89 \\
0.43 \\
1 \cdot 21 \\
1 \cdot 31\end{array}$ & $\begin{array}{l}13 \\
14 \\
14 \\
14\end{array}$ & $\begin{array}{l}\text { NS } \\
\text { NS } \\
\text { NS } \\
\text { NS }\end{array}$ & $\begin{array}{l}0.26(n=8) \\
0.08(n=8) \\
1.4 \quad(n=8) \\
137 \quad(n=8)\end{array}$ & $\begin{array}{l}0.26(n=6) \\
0.09(n=6) \\
1.8 \quad(n=6) \\
131 \quad(n=6)\end{array}$ & $\begin{array}{l}0.09 \\
0.60 \\
1 \cdot 33 \\
0.38\end{array}$ & $\begin{array}{l}12 \\
12 \\
12 \\
12\end{array}$ & $\begin{array}{l}\text { NS } \\
\text { NS } \\
\text { NS } \\
\text { NS }\end{array}$ \\
\hline $\begin{array}{l}\text { Chrysotile } \\
\text { exposure for } \\
18 \text { days } \\
\text { (C3) }\end{array}$ & $\begin{array}{l}\text { Resistance } \\
\text { Compliance } \\
\text { Tidal volume } \\
\text { Breathing rate }\end{array}$ & $\begin{array}{l}0 \cdot 23(n=5) \\
0 \cdot 25 \quad(n=5) \\
5 \cdot 2 \quad(n=5) \\
74 \quad(n=5)\end{array}$ & $\begin{array}{l}0 \cdot 26(n=5) \\
0 \cdot 22(n=5) \\
4 \cdot 8 \quad(n=5) \\
78 \quad(n=5)\end{array}$ & $\begin{array}{l}2 \cdot 88 \\
1 \cdot 15 \\
0 \cdot 86 \\
0 \cdot 46\end{array}$ & $\begin{array}{l}8 \\
8 \\
8 \\
8\end{array}$ & $\begin{array}{l}0.02 \\
\text { NS } \\
\text { NS } \\
\text { NS }\end{array}$ & $\begin{array}{l}0 \cdot 31(n=4) \\
0 \cdot 12(n=4) \\
2 \cdot 5 \quad(n=4) \\
180(n=4)\end{array}$ & $\begin{array}{l}0 \cdot 37(n=5) \\
0 \cdot 12(n=5) \\
2 \cdot 8 \quad(n=5) \\
157(n=5)\end{array}$ & $\begin{array}{c}2.51 \\
0.30 \\
1 \cdot 05 \\
0.90\end{array}$ & $\begin{array}{l}7 \\
7 \\
7 \\
7\end{array}$ & $\begin{array}{r}<0.05 \\
>0.02 \\
\mathrm{NS} \\
\mathrm{NS} \\
\mathrm{NS}\end{array}$ \\
\hline
\end{tabular}

* Measurements as in Table 5.

position along the chamber when the dust feed was held as steady as possible. These results indicate a gradient of fibre concentration $(>5 \mu \mathrm{m})$ along the chamber: the percentage reductions were very similar for both chrysotile and amosite aerosols.

With regard to the relationship between fibre concentration $(>5 \mu \mathrm{m})$ and tyndallometer reading for both aerosols, for a given tyndallometer reading the chrysotile aerosol contained a considerably higher concentration of long fibres $(>5 \mu \mathrm{m})$, than did the amosite aerosol. For example, to obtain the desired tyndallometer readings between 20 and $30 \mu \mathrm{A}$ the aerosol would need to contain between 1000 and 2000 fibres $/ \mathrm{ml}$ of amosite, or more than 5000 fibres $/ \mathrm{ml}$ of chrysotile.

COMPARISON OF RESPIRATORY FUNCTION OF ANIMALS FROM THE FRONT AND REAR CAGES

Mean respiratory function values for the groups of exposed animals in the front and rear cages are given in Tables 5 and 6 for amosite and chrysotile exposure respectively. Preliminary measurements were made during the week before exposure. The first measurements after exposure were made two weeks from the start of nine-day exposures, and at three weeks from the start of 18-day exposures. The only significant difference between these groups was resistance determined in the second group of 18-day chrysotile exposure animals. This difference was significant both before and after exposure and thus cannot have resulted from any difference in conditions during exposure.

\section{Discussion}

The changes in respiratory function of control animals during this study were similar to those reported by MacFarland et al. (1971) for Cynamolgus monkeys. They found that pulmonary 
resistance tended to fall, while pulmonary compliance and tidal volume tended to rise. These changes were attributed to the maturation of animals over the 78week experiment. No change in breathing rate was observed, although a later experiment did show a slight fall (Eckardt et al., 1972).

Maturation of the animals is also the most probable explanation for the changes seen in the present study although these changes could not be directly attributed to changes in body weight. Resistance fell when weight was increasing, but both compliance and tidal volume still tended to increase after the animals were eight months old, when weight was gradually decreasing. These changes could not be attributed to relative proportions by volume of the lung components measured, which were found to be independent of age between 4 and 28 months. Dunnill (1962b) found that the relative volumes occupied by alveolar air, alveolar duct air and vessels in human lungs remained similar from birth until 98 years of age.

$A$ reduction in the number of fibres longer than $5 \mu \mathrm{m}$, both per unit volume of air sampled and as a proportion of the total fibre concentration, was found as distance from the dust generator increased. These changes can be explained by differences in weight, with longer (heavier) fibres settling out before shorter ones. It is therefore probable that the concentration of long fibres at a given point along the chamber would be greater around guinea pigs at floor level than in the uppermost sampling level. It also follows that the concentration of short fibres along the chamber would remain more uniform than the concentration of long fibres.

If the average value of tyndallometer reading is assumed to fall within the attempted standard range of 20-30 $\mu \mathrm{A}$, then the calibrations indicate that the overall concentration of long fibres $(>5 \mu \mathrm{m})$ would have been about four times greater during chrysotile than during amosite exposure. However, it was estimated that fibres longer than $5 \mu \mathrm{m}$ accounted for $20 \%$ of the total fibres in the chrysotile aerosol, but only $10 \%$ in the amosite one. Thus the total fibre concentrations of these aerosols were more alike than would be suggested by the long fibre concentrations alone.

The individual exposure conditions proved to be impossible to define accurately. Samples were not collected from the air immediately surrounding the animals, and the dust concentration varied both with time and position along the chamber. The effects of spatial relationships of the animals, such as huddling together, on the dust content of their microenvironment was also impossible to assess. However, the results do show that the guinea pigs were exposed to very high concentrations of short fibres and con- centrations of long fibres $(>5 \mu \mathrm{m})$ at least of the order of $1000 \mathrm{fibres} / \mathrm{ml}$. Such high dust concentrations were thought necessary to produce asbestotic lesions within the time-span of these experiments.

There were no significant differences in respiratory function of those animals exposed in the front cages or those in the rear cages, that could be attributed to differences in the exposure conditions. The timing of the first measurement after exposure was thought to be optimal for detection of any such differences, as the disturbances of respiratory function were maximal at this time and the numbers of animals in each group were at their highest (see Part II, (British Journal of Industrial Medicine, 1978, 35, 135-145)). This uniformity of respiratory function suggests that, if the initial changes in the lung are dose-dependent, then they must be more closely related to the concentration of short fibres than to that of long fibres, as the former were more uniformly distributed during exposure. Further aspects of dose-dependence of response after exposure to high concentrations of asbestos dust are dealt with in the discussion following Part II.

I am indebted to Dr P. F. Holt, Department of Chemistry, University of Reading, for making available his inhalation equipment, and Dr S. Holmes, Health Physics Department, Turner Brothers Asbestos Co. Ltd., Rochdale, for help with the dust sampling. I would like to thank Dr H. C. Lewinsohn, Turner Brothers Asbestos Co. Ltd., Rochdale, Dr G. Williams, Department of Pathology, University of Manchester and Professor W. R. Lee, Department of Occupational Health, University of Manchester, for their helpful advice, and Mr R. D. Morrisey for his technical assistance. I am grateful to the Asbestosis Research Council for financial support of this work.

\section{References}

Bader, M. E., Bader, R. A., Tierstein, A. S., Miller, A., and Selikoff, I. J. (1970). Pulmonary function and radiological changes in 598 workers with varying duration of exposure to asbestos. Mount Sinai Journal of Medicine, 37, 492-500.

Becklake, M. R., Fournier-Massey, G., Rossiter, C. E., and McDonald, J. C. (1972). Lung function in chrysotile asbestos mine and mill workers in Quebec. Archives of Environmental Health, 24, 401-409.

Coleman Muldoon, B., and Turner Warwick, M. (1972). Lung function studies in asbestos workers. British Journal of Diseases of the Chest, 66, 121-132.

Dunnill, M. S. (1962a). Quantitative methods in the study of pulmonary pathology. Thorax, 17, 320-328.

Dunnill, M. S. (1962b). Postnatal growth of the lung. Thorax, 17, 329-333.

Eckardt, R. E.. Linden, N. J., MacFarland, H. N., Alarie, Y., and Busey, W. M. (1972). The biological effect of long- 
term exposure of primates to carbon monoxide. Archives of Environmental Health, 25, 381-387.

Harness, I. (1973). Airborne asbestos dust evaluation. Annals of Occupational Hygiene, 16, 397-404.

Hiett, D. M. (1974). Tests of ventilatory function for use in long-term studies. British Journal of Industrial Medicine, 31, 53-58.

Holt, P. F., Mills, J., and Young, D. K. (1964). The early effects of chrysotile asbestos dust on the rat lung. Journal of Pathology and Bacteriology, 87, 15-23.

Holt, P. F., Mills, J., and Young, D. K. (1966). Experimental asbestosis in the guinea pig. Journal of Pathology and Bacteriology, 92, 185-195.
MacFarland, H. N., Ulrich, C. E., Martin, A., Krumm, A., Busey, W. M., and Alarie, Y. (1971). Chronic exposure of Cynamolgus monkeys to fly ash. In Inhaled Particles III, volume 1, pp 313-326. Edited by W. H. Walton. Unwin Brothers: Old Woking, Surrey.

Timbrell, V., and Skidmore, J. W. (1968). Significance of fibre length in experimental asbestosis. In Biologische Wirkungen des Asbestes, Internationale Konferenz, Dresden (Deutsches Zentralinstitut für arbeitsmedizin, Berlin, Gesellschaft für arbeitshygiene und arbeitsshutz inder $D D R$ ), pp 52-56. Edited by E. Holstein, Dresden.

Wagner, J. C. (1963). Asbestosis in experimental animals. British Journal of Industrial Medicine, 20, 1-12. 